\title{
Phelipanche chionistrae (Orobanchaceae): a new holoparasitic species from Cyprus
}

\author{
Stefan Rätzel, Ralf Hand, Charalambos S. Christodoulou \& Holger Uhlich
}

\begin{abstract}
RÄTZEL, S., R. HAND, C.S. CHRISTODOULOU \& H. UHLICH (2021). Phelipanche chionistrae (Orobanchaceae): a new holoparasitic species from Cyprus. Candollea 76: 77-82. In English, English abstract. DOI: http://dx.doi.org/10.15553/c2021v761a7

The new species Phelipanche chionistrae Rätzel, Hand, Christodoulou \& Uhlich (Orobanchaceae) is described from Chionistra, the highest summit of the Troodos range in Cyprus. Morphological data strongly suggest affinities to the Phelipanche rosmarina complex, predominantly West Mediterranean taxa, and Phelipanche olbiensis (Coss.) Carlón et al. The new taxon can be distinguished by a combination of characters such as general colouration, structure of calyx and type of indumentum. Also, it has a different ecology being restricted to a high-montane serpentinophytic coenosis. Currently, only a few populations of the taxon, which is a parasite mainly on the Cypriot endemic Alyssum troodi Boiss. (and possibly other serpentinophilous species), are known. According to the IUCN Red List Categories and Criteria it should be assessed as "Near Threatened".
\end{abstract}

\section{Keywords}

OROBANCHACEAE - Phelipanche - Cyprus - Mediterranean - Serpentinophyte - New species

Addresses of the authors:

SR: Georg-Friedrich-Händel-Str. 13, D-15234 Frankfurt/Oder, Germany.

RH: Winterfeldtstr. 25, D-10781 Berlin, Germany.

CSC: Department of Forests, Ministry of Agriculture, Rural Development and Environment, 26 Louki Akrita street, CY-1414 Lefkosia, Cyprus.

HU: Gartenstr. 19, D-56357 Welterod, Germany. E-mail: uhlich.holger@googlemail.com

Submitted on May 20, 2020. Accepted on December 4, 2020.

First published online on February 1, 2021.

ISSN : 0373-2967 - Online ISSN : 2235-3658 - Candollea 76(1): 77-82 (2021)

C CONSERVATOIRE ET JARDIN BOTANIQUES DE GENÈVE 2021 


\section{Introduction}

The genus Phelipanche Pomel (= Orobanche sect. Trionychon Wallr.; RÄTzel et al., 2017a) which has been accepted as a segregate genus from Orobanche L. by several authors (e.g. SchneEweiss, 2013; RÄTzel et al., 2017a) comprises currently about 60-72 species. Phelipanche shows centres of diversification in the West Mediterranean as well as in Asia Minor, Iran and Transcaucasia. Determination of its taxa can be challenging. Many species prove to be poor in diagnostic characters. On the other hand, various characters are extremely variable and difficult to compare, particularly in widespread taxa. Furthermore, many species can be found only very scattered in much fragmented distribution areas and appear irregularly. These facts complicate fieldwork considerably, especially in remote areas.

Recent studies have clarified the taxonomy of various poorly understood taxa, resulting in the description of several new species from the above-mentioned regions (e.g. CARLón et al., 2005, 2008; RÄTzEL et al., 2017a).

Several collections that could not be identified with any known species have been made recently in Cyprus, the largest island of the East Mediterranean, which is a biodiversity and endemism hotspot (e.g. Myers et al., 2000; Hadjisterkotis, 2008; MÉdail \& Diadema, 2009). These collections represent a new species that is formally described here as Phelipanche chionistrae Rätzel, Hand, Christodoulou \& Uhlich.

Our study is based on the long-term fieldwork in Cyprus by $\mathrm{CSC}$ and $\mathrm{RH}$ and extensive field and herbarium studies by $\mathrm{SR}$ and HU of the vast majority of Euro-Mediterranean Phelipanche taxa, some of which currently have no valid combination under that genus and are therefore referred to here by their Orobanche names. Materials preserved in the following herbaria have been studied: B, COI, CYP, G, JE, K, MB, NMNH, P, W, WU and the private herbarium of Georgios Hadjikyriakou.

\section{Taxonomic treatment}

Phelipanche chionistrae Rätzel, Hand, Christodoulou \& Uhlich, sp. nov. (Fig. 1,2).

Holotypus: Cyprus. Distr. Lemesos: Troodos, by forest road to Kakopetria not far away from turn-off from Prodromos road, $1795 \mathrm{~m}, 34^{\circ} 56^{\prime} 29^{\prime \prime N} 32^{\circ} 51^{\prime} 55^{\prime \prime E}, 16$.VI.2018, Hand 9011 (B [B 10 1067919]! image available at https:// herbarium.bgbm.org/object/B101067919).

Phelipanche chionistrae Rätzel, Hand, Christodoulou E Ublich is similar to P. olbiensis (Coss.) Carlón and P. rosmarina (Beck) Banfi s.l. but differs by its calyx teeth shorter than the calyx tube to equally long. Phelipanche chionistrae further differs from $P$. olbiensis by the longer indumentum of corolla and corolla lobes, by the mostly shorter corolla, by the elongated, longer and more hairy anthers and by the different host spectrum. Phelipanche chionistrae differs from P. rosmarina s.l. by the shorter indumentum of the stem, bracts, and calyx, by the shorter corolla, by the longer and more hairy anthers, by the strict specialization on serpentine substrate and by the different host spectrum.

Plant (5.5-)6.5-8(-12) cm tall, intensely coloured in all parts (except throat bulges). Stem gracile, c. 1.2-3(-4.5) $\mathrm{mm}$ in diam., simple (very rarely with few branches), sparsely scaly, blackish-dark red to brownish-violet, turning pale brown lower down and dark brown higher up in dried stage, densely light glandular hairy; glandular hairs $0.1-0.2 \mathrm{~mm}$ long, with yellowish glands. Scales sparse, 5-7(-8) mm long, colouration as in stem, dark brown in dried stage, glandular hairy, glabrous at the base, the lower ones broadly ovate, obtuse to triangular-acuminate, the upper ones narrowly triangularacuminate, apically sometimes \pm cucullate. Spike few-flowered, with (3-)5-10(-12) flowers, $2-5 \mathrm{~cm} \times$ c. $2 \mathrm{~cm}$ wide, usually \pm dense and distinctly shorter than the remaining stem. Bracts 5-7 × 3-4 mm, same colour as the stem, dark brown in dried stage, broadly based triangular-acuminate, whitish glandular hairy (hairs $0.1-0.2 \mathrm{~mm}$ long), indistinctly multi-veined, shorter than the calyx teeth, reaching as far as the constriction of the corolla. Bracteoles lanceolate, 4-5 × 1-1.4 mm, same colour as the stem, dark brown in dried stage, somewhat shorter than the calyx teeth, with short light glandular hairs. Calyx 4-toothed, relatively robust, 6-7 mm long; teeth broadly based narrowly triangular-acuminate, shorter than the calyx tube (rarely lanceolate and about as long as the calyx tube), reaching somewhat beyond the point of insertion of the stamens, same colour as the stem and the bracts, densely light glandular hairy; hairs 0.1-0.2 mm long. Corolla (9-)10-13(-15) $\mathrm{mm}$ long, erecto-patent, narrowly tubular, slightly curved above the constriction, whitish base largely hidden in the calyx tube, otherwise intensely dark purplish-violet (blackish purple in the budding state), veins indistinctly darker, externally with numerous light glandular hairs; hairs $0.1-0.25 \mathrm{~mm}$ long. Upper lip 2-lobed; lobes rectangular, vertically erect or slightly recurved, with whitish, eglandular, multicellular hairs outside and apically inside, densely hairy on the margins; hairs 0.2-0.35 mm long. Lower lip 3-lobed; lobes approx. equal, rounded to rarely slightly acuminate, antrorse or ligulate in the distal half, somewhat recurved downwards; indumentum as in upper lip. Throat bulges white, with antrorse to erect hairs. Filaments inserted 3-3.5 $\mathrm{mm}$ above the base of the corolla tube, whitish hairy at the lowest quarter, otherwise glabrous; hairs 0.2-0.4 mm long. Anthers white, oblong, 1.1-1.4 × 0.8-0.9 mm, apically \pm acuminate, with up to $0.4 \mathrm{~mm}$ long curly hairs at base and suture. Ovary ovate, apically narrowed to the style base. Style hyaline glandular hairy, densely hairy below stigma; hairs c. $0.1 \mathrm{~mm}$ long. Stigma 2-lobed, \pm light yellow. Seeds dark brown, variously shaped, most often ovate, but also rounded or polygonal, c. $0.2 \times 0.4 \mathrm{~mm}$. 

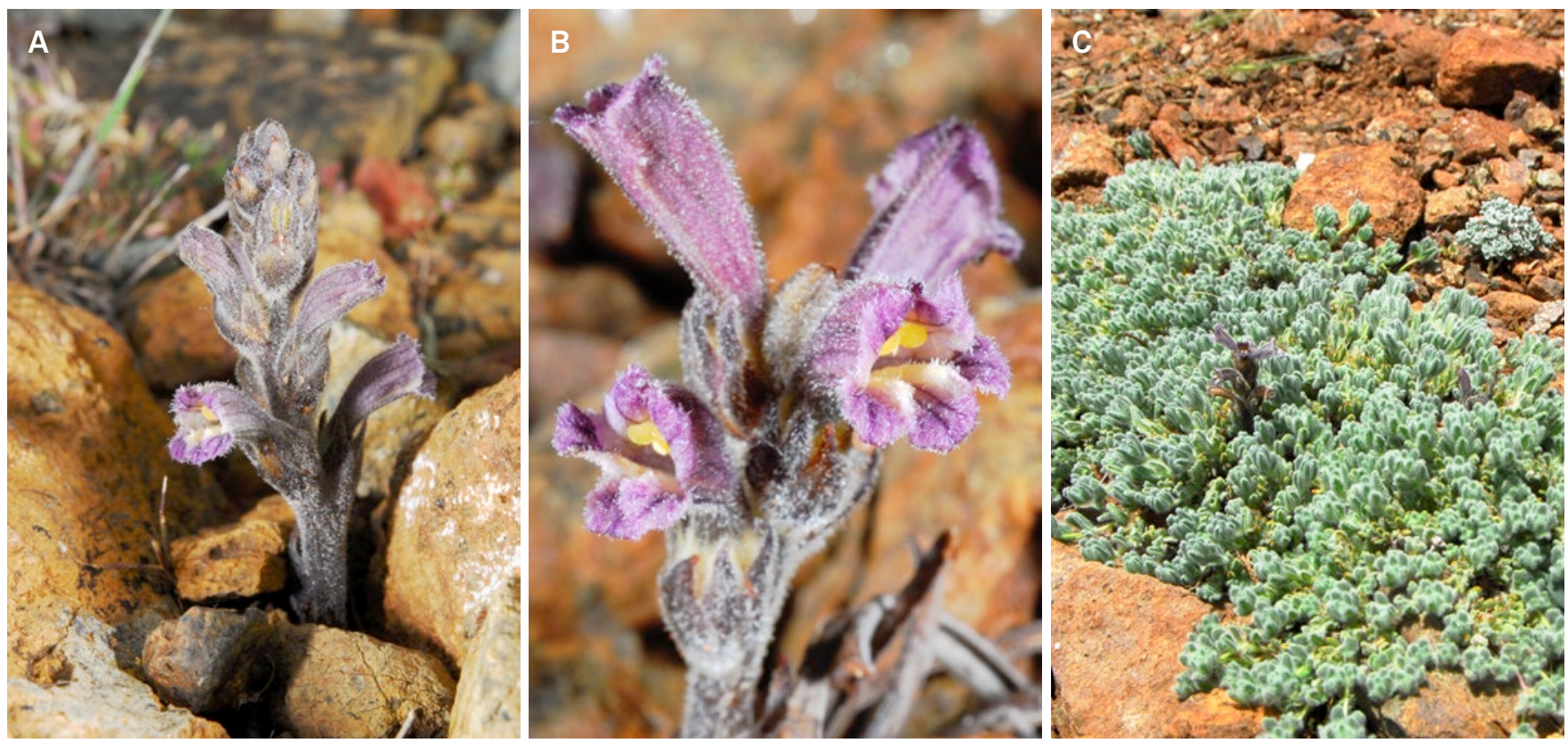

Fig. 1. - Phelipanche chionistrae Rätzel, Hand, Christodoulou \& Uhlich in Mt Chionistra. A. Single plant habit; B. Inflorescence; C. Habitat, plants in Teucrium cyprium Boiss.

[Photos: C.S. Christodoulou]

Etymology. - The epithet chionistrae refers to the Mt. Chionistra, colloquially also known as Mt. Olympos, reaching $1.952 \mathrm{~m}$ above sea level and forming the highest elevation of both the Troodos range and the island of Cyprus.

Distribution and habitat. - Phelipanche chionistrae seems to be endemic to the highest altitudes of Mt. Chionistra (Fig. 3). Meikle (1985) does not cite any material from the higher altitudes of Mt. Chionistra under the name Orobanche ramosa s.l. possibly because of its relative rareness. The summit consists of Upper Cretaceous, more or less serpentinized and tectonized harzburgites which belong to the Troodos ophiolite complex (GSD, 1995). The vegetation of the peak is generally dominated by very open stands of Pinus nigra subsp. pallasiana (D. Don) Holmboe. Phelipanche chionistrae has been found on large openings with sparse vegetation cover, often less than $10 \%$. The terrain is extremely rocky complicating the determination of hosts of the new taxon, which sometimes grows in clefts of bare serpentine rocks at considerable distance from any other vascular plant. Hitherto, it has only been found at an altitude of 1500-1900 m.

Phenology. - Flowering individuals of P. chionistrae have been found from May to June.

Conservation status. - Phelipanche chionistrae was first observed in 2009 and since then several small populations (1-20 plants) have been located at eight places on the higher parts of Mt. Chionistra in an area of $10 \mathrm{~km}^{2}$, all found within the Troodos National Forest Park, which is also a Natura 2000 site, with controlled human activities. However, climate change is a potential threat for this high-altitude species. Considering the protected status of its distribution area, the low level of threat, the small known population $(<1000)$ and the restricted Area of Occupancy $\left(<10 \mathrm{~km}^{2}\right)$ (IUCN, 2012) as well as incalculable habitat changes as a result of climate change (e.g., Giannakopoulos et al., 2010; Hadjinicolaou et al., 2011), the species could be preliminary assessed as "Near threatened" [NT]. Further surveys are needed in the higher peaks of central Troodos such as neighbouring Madari and Papoutsa peaks to better understand its distribution.

Notes. - Phelipanche chionistrae parasitizes Alyssum troodi Boiss. (Brassicaceae), most probably Teucrium cyprium Boiss. (Lamiaceae; Fig. 1C) and possibly Alyssum cypricum Nyár. and Hypericum confertum subsp. stenobotrys (Boiss.) Holmboe (Hypericaceae) but does definitely not parasitize Rosmarinus officinalis L. (Lamiaceae).

Current opinion is divided as regards the taxonomy of species that obligately parasitize Rosmarinus officinalis L. We treat here these species as a complex including Phelipanche rosmarina (Beck) Banfi et al. s.str., Orobanche mariana A. Pujadas, Phelipanche pseudorosmarina (A. Pujadas \& Muñoz Garm.) Uhlich and Orobanche rumseyana A. Pujadas $\&$ P. Fraga. This complex may represent different species and does not necessarily mean a definite synonymisation advocated 

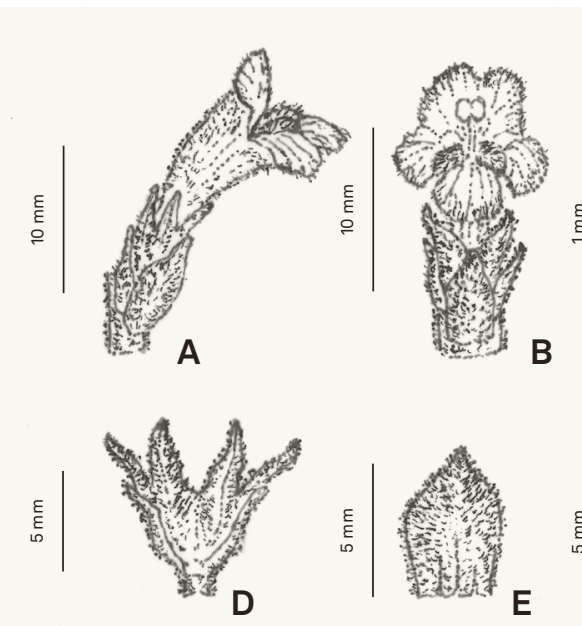

B
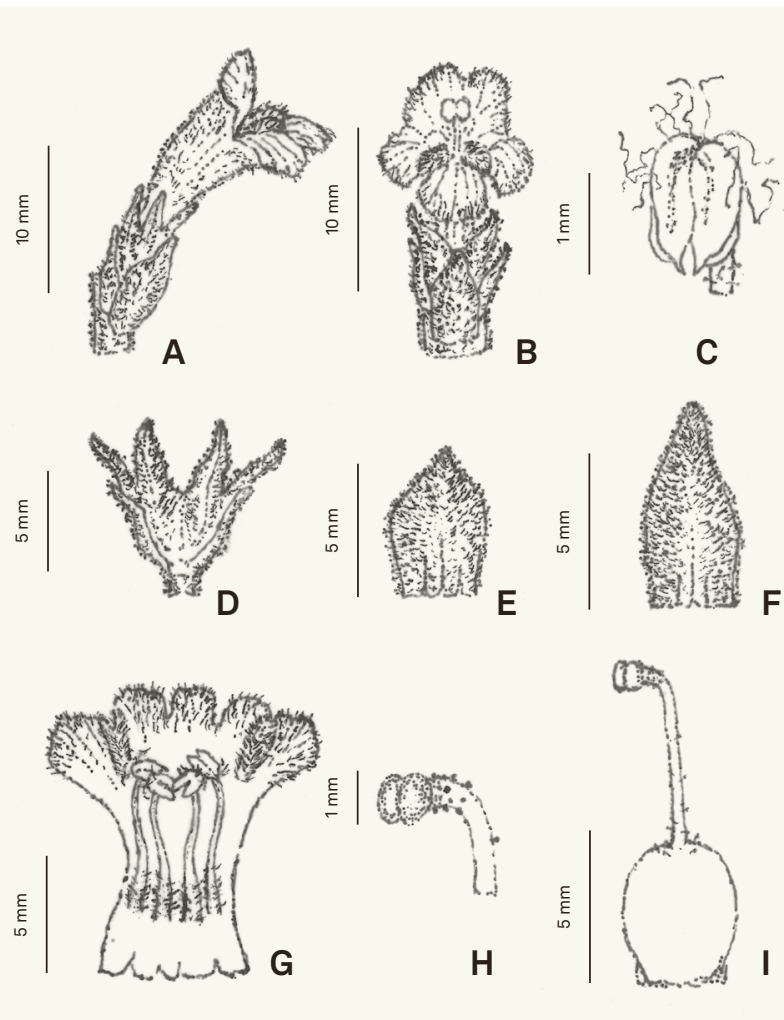

Fig. 2. - Phelipanche chionistrae Rätzel, Hand, Christodoulou \& Uhlich. A. Flower, side view; B. Flower, front view; C. Anther;

D. Calyx and bracteoles; E. Bract, outside; F. Stem scale, outside; G. Corolla, open, inside with stamens; H. Stigma and upper part of the style; I. Ovary with style and stigma.

[Drawings: S. Rätzel]

by Sánchez-Pedraja et al. (2020). Phelipanche chionistrae is morphologically closely related to Phelipanche olbiensis (Coss.) Carlón et al. and the Phelipanche rosmarina complex. Morphological comparison can be found in Table 1 . Several diagnostic characters are lost in herbarium specimens of Orobanchaceae and they need to be studied in fresh material. This is the case for example of the indumentum in P. olbiensis which provides a good diagnostic character (Table 1). Its flowering shoots are densely covered with short glandular hairs with relatively large yellow-hyaline heads; longer glandular hairs are scarce or lacking. Depending on the light conditions, plants look matt velvety or glittering (Fig. 4A). As it contrasts with the colour of the stem and bracts this character can be clearly seen. All other taxa have a rather silky indumentum (Fig. 4B) which is caused by a mixture of short and long glandular hairs with smaller, inconspicuous glandular head that cover stem and bracts.

Phelipanche chionistrae also differs by its preference for higher altitudes. With the exception of P. sinaica (Beck) Rätzel \& Uhlich which however shows a differing host spectrum, the other taxa prefer lower altitudes (sea-level up to c. $650 \mathrm{~m}$ ). Phelipanche sinaica differs from P. chionistrae by

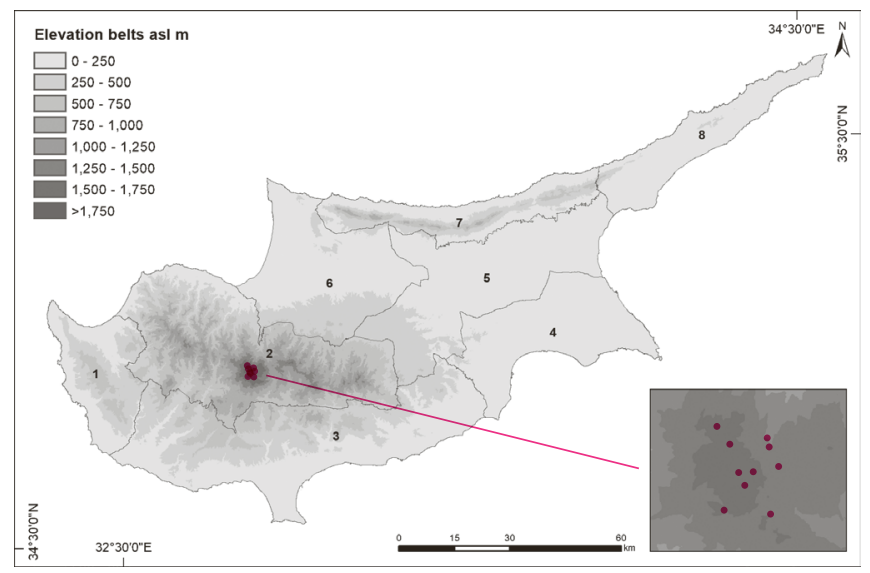

Fig. 3. - Distribution map of Phelipanche chionistrae Rätzel, Hand, Christodoulou \& Uhlich in Cyprus and in the central Troodos range (inlay). Elevation is represented in levels of grey. Phytogeographical divisions follow MEIKLE (1985).[Map: A. Antoniou \& K. Papasavvas]

its permanently compact inflorescences which are relatively rich in flowers (c. (8-)14-28(-30) vs. c. 3-10(-12)) and by its paler to dull violet corollae. Phelipanche sinaica parasitizes Lactuca viminea (L.) J. Presl \& C. Presl and it is known to occur in Azerbaijan, Egypt and Iran (Rätzel et al., 2017b). Apart from P. nowackiana (Markgr.) Soják, a NE Mediterranean species that also parasitizes perennial taxa of Alyssum s.l., Phelipanche chionistrae is the second species known to be a strict serpentinophyte.

Additional specimens examined. - Cyprus. Distr. Lemesos: Chionistra, near giant Pinus nigra tree, 1850 m, 12.VI.2009, Christodoulou s.n. (B); ibid. loco, on S slopes of massif, $1735 \mathrm{~m}, 34^{\circ} 55^{\prime} 08^{\prime \prime} \mathrm{N} 32^{\circ} 51^{\prime} 31^{\prime \prime} \mathrm{E}, 22 . \mathrm{V} .2013$, Hand $\mathcal{G}^{\circ}$ Christodoulou 6104 (B); ibid. loco, 1825 m, 34 55'59"N 3252'26"E, 30.V.2013, Christodoulou s.n. (B). Distr. Lefkosia: Troodos, on forest road to Kakopetria, towards N Shoulder, close to seismological station on top $\mathrm{E}$ of forest road, 1828 m, 34 ${ }^{\circ} 56^{\prime} 49^{\prime \prime N} 32^{\circ} 51^{\prime} 38^{\prime \prime E}, 16 . V I .2018$, Hand 9013 (B); 300 m S of Kannoures spring, $1550 \mathrm{~m}, 34^{\circ} 56^{\prime} 26^{\prime \prime} \mathrm{N} 032^{\circ} 52^{\prime} 47^{\prime \prime} \mathrm{E}, 24 . V I .2019$, Hadjikyriakou 7754 (Herb. Hadjikyriakou); Kannoures spring, 1500 m, 34 ${ }^{\circ} 56^{\prime} 36^{\prime \prime N} 32^{\circ} 52^{\prime} 45^{\prime \prime} \mathrm{E}$, 18.VII.2019, Hadjikyriakou 7762 (Herb. Hadjikyriakou).

\section{Acknowledgements}

We are grateful to the staff of the herbaria at B and G, namely Nicolas Fumeaux (Geneva), Sarah Bollendorff and Peter Hein (B). Michael Ristow (Berlin, Potsdam) helped in many ways. For permission to use images we thank Pedro Pinho [www. flora-on.pt], Armin Jagel and Thomas Schmitt (both Bochum). Georgios Hadjikyriakou (Trachoni Lemesou) and Christodoulos Makris (Lemesos) provided us with data on additional specimens and field records respectively. Andreas Antoniou and Konstantinos Papasavvas (Lefkosia) kindly produced the distribution map. We would also like to thank the two reviewers for their valuable advice. Leslie Lewis (Chepstow) kindly corrected the manuscript linguistically. 

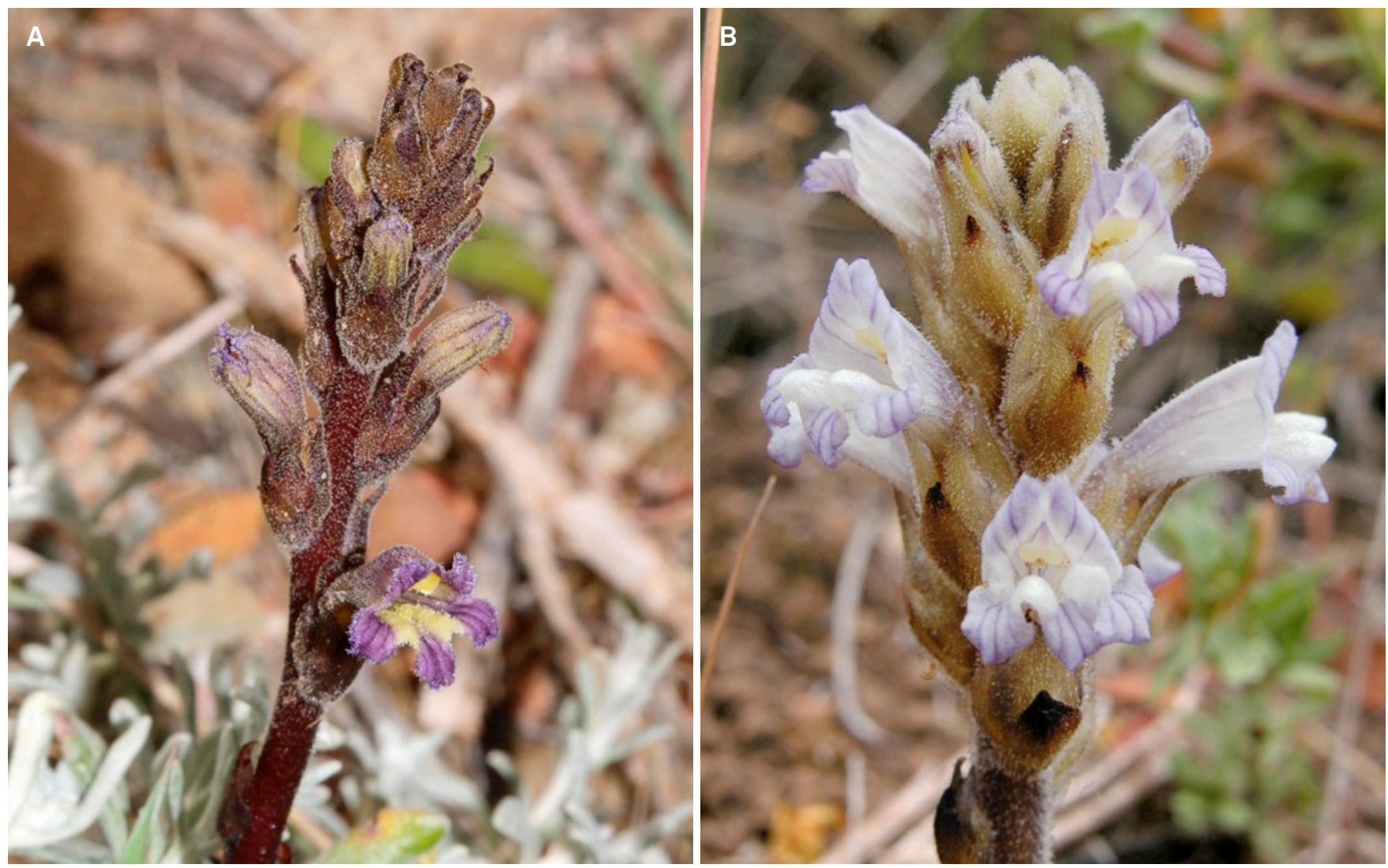

Fig. 4. - A. Phelipanche olbiensis (Coss.) Carlón et al. on Helichrysum L. in Crete, Greece; B. Phelipanche rosmarina (Beck) Banfi et al., Serra dos Candeeiros in Portugal.

[Photos: A: A. Jagel \& T. Schmitt; B: P. Pinho]

\section{References}

Carlón, L., G. Gómez Casares, M. Laínz, G. Moreno Moral, Ó. Sánchez Pedraja \& G.M. Schneeweiss (2005). Más, a propósito de algunas Orobanche L. y Phelipanche Pomel del oeste del Paleártico. Doc. Jard. Bot. Atlántico 3: 1-71.

Carlón, L., G. Gómez Casares, M. Laínz, G. Moreno Moral, Ó. Sánchez Pedraja \& G.M. Schneeweiss (2008). Más, a propósito de algunas Phelipanche Pomel, Boulardia F.W. Schultz y Orobanche L. (Orobanchaceae) del oeste del Paleártico. Doc. Jard. Bot. Atlántico 6: 1-128.

Giannakopoulos, C., P. Hadjinicolaou, E. Kostopoulou, K.V. Varotsos \& C. Zerefos (2010). Precipitation and temperature regime over Cyprus as a result of global climate change. Adv. Geosci. 23: 17-24.

GSD [Geological Survey Department] (1995). Geological map of Cyprus. Revised Edition. Ministry of Agriculture, Natural Resources and Environment, Lefkosia.

Hadjinicolaou, P., C. Giannakopoulos, C. Zerefos, M.A. Lange, S. Pashiardis \& J. Lelieveld (2011). Mid-21st century climate and weather extremes in Cyprus as projected by six regional climate models. Regional Environmental Change 11(3): 441-457.
HAdjISTERKotis, E. (2008). Review of biodiversity research results from Cyprus that directly contribute to the sustainable use of biodiversity in Europe. Unit of Environmental Studies, Research Center Intercollege, Lefkosia.

IUCN (2012). IUCN Red List Categories and Criteria: Version 3.1. Ed. 2. IUCN Species Survival Commission, Gland \& Cambridge.

Médail, F. \& K. Diadema (2009). Glacial refugia influence plant diversity patterns in the Mediterranean Basin. J. Biogeogr. 36: 1333-1345.

Meikle, R.D. (1985). Fl. Cyprus 2. The Bentham-Moxon Trust, Kew.

Myers, N., R.A. Mittermeier, C.G. Mittermeier, G.A. Da Fonseca \& J. Kent (2000). Biodiversity hotspots for conservation priorities. Nature 403: 853-858.

RätZel, S., M. Ristow \& H. Uhlich (2017a). Bemerkungen zu ausgewählten Vertretern der Gattung Phelipanche Pomel im östlichen Mittelmeergebiet mit der Beschreibung von Phelipanche hedypnoidis Rätzel, Ristow \& Uhlich, sp. nov. Carintbia II 207: 643-684.

Rätzel, S., M. Ristow \& H. Uhlich (2017b). Phelipanche sinaica (Beck) Rätzel \& Uhlich comb. \& stat. nov. In: RAAB-Straube, E. von \& T. Raus (ed.), Euro+Med-Checklist Notulae, 8 
[Notulae ad floram euro-mediterraneam pertinentes No. 37].

Willdenowia 47: 302-304.

Sánchez Pedraja, Ó., G. Moreno Moral, L. Carlón, R. Piwowarczyk, M. Laínz \& G.M. Schneeweiss (2020). Index of Orobanchaceae. Liérganes, Cantabria, Spain. [http://www.farmalierganes.com/Otrospdf/publica/Orobanchaceae\%20Index.htm]

Schneeweiss, G.M. (2013). Phylogenetic relationships and evolutionary trends in Orobanchaceae. In: Joel, D.M. et al. (ed), Parasitic Orobanchaceae. Parasitic Mechanisms and Control Strategies: 243-265. Springer.

Table 1. - Comparison of morphological characters and hosts between Phelipanche chionistrae Rätzel, Hand, Christodoulou \& Uhlich, the $P$. rosmarina complex and $P$. olbiensis (Coss.) Carlón et al. Characters diagnostic for one species are in bold.

\begin{tabular}{|c|c|c|c|c|}
\hline & & P. rosmarina s.l. & P. chionistrae & P. olbiensis \\
\hline Habit & plant height [cm] & $(4-) 6-26(-35)$ & $(5.5-) 6.5-8(-12)$ & $(3-) 5-12(-17)$ \\
\hline \multirow[t]{2}{*}{ Stem } & colour & $\begin{array}{l}\text { pale, partly greyish, rarely } \\
\text { reddish brown }\end{array}$ & $\begin{array}{l}\text { dark brown-purple to red- } \\
\text { brown, blackish purple in bud }\end{array}$ & $\begin{array}{l}\text { dark brown-purple to red- } \\
\text { brown, blackish purple in bud }\end{array}$ \\
\hline & hairs length [mm] & $(0.1-) 0.2-0.4(-0.9)$ & $0.1-0.2$ & $0.1-0.15$ \\
\hline Bracts & glandular hairs length [mm] & $0.2-0.5(-0.6)$ & $0.1-0.2$ & $\leq 0.1$ \\
\hline \multirow{3}{*}{ Calyx } & length $[\mathrm{mm}]$ & $8-10$ & $6-7$ & $(6-) 7-9(-11)$ \\
\hline & relation teeth to tube & somewhat longer & $\begin{array}{l}\text { somewhat shorter up to as } \\
\text { long }\end{array}$ & somewhat longer \\
\hline & hairs length [mm] & $0.3-0.6$ & $0.1-0.2$ & $0.1-0.2$ \\
\hline \multirow{3}{*}{ Corolla } & length $[\mathrm{mm}]$ & $(12-) 14-18$ & $(9-) 10-13(-15)$ & $(10-) 12-16(-18)$ \\
\hline & $\begin{array}{l}\text { tube glandular hairs length } \\
{[\mathrm{mm}]}\end{array}$ & $(0.1-) 0.15-0.25(-0.4)$ & $(0.1-) 0.15-0.25$ & $0.05-0.1(-0.2)$ \\
\hline & $\begin{array}{l}\text { lobes and folds eglandular } \\
\text { hairs length }[\mathrm{mm}]\end{array}$ & $0.2-0.4(-0.5)$ & $0.2-0.3$ & $0.1-0.2(-0.3)$ \\
\hline \multirow{5}{*}{ Anther } & shape & oblong & oblong & roundish \\
\hline & $\begin{array}{l}\text { filament, height of insertion } \\
\text { [mm] }\end{array}$ & $3.5-5.0$ & $3.0-3.5$ & $2.5-3.5(-4.5)$ \\
\hline & length $[\mathrm{mm}]$ & $(0.9-) 1.2-1.5 \times(0.6-) 0.8(-1.0)$ & $1.1-1.4 \times 0.8-0.9$ & $1.1-1.3 \times 1.1-1.3$ \\
\hline & indumentum & glabrous to sparsely hairy & $\begin{array}{l}\text { basally and at suture with } \\
\text { scattered to numerous hairs }\end{array}$ & $\begin{array}{l}\text { glabrous or very sparsely } \\
\text { hairy at suture }\end{array}$ \\
\hline & hairs length [mm] & $0.2-0.4$ & $0.3-0.5$ & $0.1-0.2$ \\
\hline Host & & Rosmarinus officinalis & $\begin{array}{l}\text { Alyssum troodii, very probably } \\
\text { also Teucrium cyprium, } \\
\text { possibly Alyssum cypricum, } \\
\text { Hypericum confertum }\end{array}$ & $\begin{array}{l}\text { Helichrysum stoechas, } \\
\text { H. conglobatum, H. pendulum, } \\
\text { H. ×rhodium, Phagnalon } \\
\text { saxatile, P. rupestre subsp. } \\
\text { graecum and subsp. rupestre }\end{array}$ \\
\hline
\end{tabular}

